\title{
Transformation of ram sperm nuclei in oocytes cytoplasm during in vitro fertilization
}

\author{
Y. Dzulfiqor ${ }^{1}$, M. A. Setiadi ${ }^{1,2}$ and N. W. K. Karja ${ }^{1,2, *}$ \\ ${ }^{1}$ Post Graduate Program in Reproductive Biology, \\ Faculty of Veterinary Medicine, IPB University, Dramaga Campus, Bogor 16680 - Indonesia \\ ${ }^{2}$ Reproduction and Obstetrics Division, Department of Veterinary Clinic, \\ Reproduction and Pathology, Faculty of Veterinary Medicine, IPB University, \\ Jl. Agatis Raya, Kampus IPB Dramaga, Bogor 16680 - Indonesia \\ *Corresponding E-mail: karjanwk13@gmail.com
}

Received November 11, 2018; Accepted April 29, 2019

\begin{abstract}
ABSTRAK
Tujuan penelitian ini adalah untuk memahami transformasi inti sperma domba di dalam sitoplasma oosit saat fertilisasi secara in vitro. Oosit didapatkan dari rumah potong hewan. Sebelum fertilisasi, oosit dimatangkan secara in vitro selama 24 jam. Oosit $(n=635)$ kemudian difertilisasi dengan sperma $\left(5 \times 10^{6}\right.$ spermatozoa/ $\mathrm{ml}$ ) dalam inkubator dengan $5 \% \mathrm{CO}_{2}$ pada $38.5^{\circ} \mathrm{C}$. Proses inkubasi dilakukan selama 3,6 , 9,12 , dan 15 jam untuk setiap perlakuan. Setelah fertilisasi selesai, oosit difiksasi dan diwarnai dengan aceto-orcein $2 \%$ sebelum dievaluasi dengan mikroskop fase kontras. Transformasi inti sperma dievaluasi sesuai dengan status inti dari sperma, seperti kondensasi, dekondensasi, dan pembentukan prepronukleus dan pronukleus. Kondensasi dan dekondensasi sperma terlihat pada tiga jam setelah inkubasi sperma dengan oosit. Enam jam setelah inkubasi ditemukan prepronukelus dan pronukelus. Pronukleus mulai terbentuk pada enam jam setelah inkubasi dan secara nyata meningkat pada sembilan jam setelah inkubasi $(\mathrm{P}<0.05)$. Kejadian polispermia mengalami peningkatan secara signifikan pada 12-15 jam setelah interaksi sperma dengan oosit $(\mathrm{P}<0.05)$. Disimpulkan bahwa penetrasi sperma ke dalam sitoplasma oosit sudah terjadi pada tiga jam periode fertilisasi. Pronukleus sudah terbentuk pada 6 jam setelah inkubasi dan kejadian polispermia meningkat seiring dengan bertambahnya waktu fertilisasi.
\end{abstract}

Kata kunci: domba, fertilisasi in vitro, inti spermatozoa, transformasi .

\begin{abstract}
The aim of present study was to understand the transformation of ram sperm nuclei within oocyte cytoplasm during in vitro fertilization. The oocytes were collected from slaughterhouse ovaries. Before fertilization, the oocytes were maturated in vitro for 24 hours in the incubator with $5 \% \mathrm{CO}_{2}$ at $38.5^{\circ} \mathrm{C}$. Then the oocytes $(\mathrm{n}=635)$ was fertilized by incubating the oocytes with sperm $\left(5 \times 10^{6}\right.$ spermatozoa/ $\left.\mathrm{ml}\right)$ for $3,6,9,12$, and 15 hours. At the end of incubating period, the oocytes were fixed and stained with aceto-orcein $2 \%$ before evaluated under phase contrast microscope. Sperm nuclear transformation was evaluated according to sperm nuclear status of sperm, such as condensation, decondensation, and formation of prepronuclei and pronuclei. Sperm condensation and decondensation were seen at 3 hours after incubation. Prepronuclei and pronuclei were found at 6 hours of incubation. Pronuclei formation was significantly increased in the 9 hours after incubation $(\mathrm{P}<0.05)$. The incidence of polyspermia was significantly increased at $12-15$ hours after incubation $(\mathrm{P}<0.05)$. In conclusion penetration of sperm into oocytes has been occurred at 3 hour of fertilization period. The formation of pronuclei was found at 6 hours after incubation and the incidence of polyspermia was increased when the fertilization period
\end{abstract}


prolonged.

Keywords: in vitro fertilization, ram, sperm nuclei, transformation

\section{INTRODUCTION}

Fertilization is defined as a process of haploid gametes fusion to produce a new diploid individual which have inherited genetic trait from its parent (Bianchi and Wright, 2016; Gilbert, 2010). Fertilization process occur within several stages which begin with penetration of sperm into the oocyte through zona pelucida (ZP) (Hirohashi and Yanagimachi, 2018; La Spina et al., 2017), acrosomal reaction (Jin et al., 2011; Hino et al., 2016), transformation of sperm which is followed by oocyte meiosis resume, fusion of genetic material from sperm and oocyte (Elder and Dale, 2011), and oocyte metabolic activation to induce embryonic development (Gilbert, 2010).

The process of nuclear transformation of sperm after fertilization occur in several steps. The sperm which has passed perivitelline space will fuse with oocyte membrane through the microvilli and equatorial postacrosomal part of spermatozoon (Sharma and Rao, 2018; Miyado et al., 2018). This event known as sperm condensation (Hafez and Hafez, 2013) that resulted in sharpened of sperm head (Dozortsev et al., 1994). The transformation of sperm be continued by decondensation process that indicated by sperm head swelling and increasing in size (Tesarik and Kopecny, 1989). The head of decondensed sperm is surrounded by vesicle from cytoplasm of oocyte (Lassalle and Testart, 1991). After decondensation, sperm will transform into prepronuclei. Prepronuclei is a reform stage of the nuclear envelope. When the nuclear envelope seen clearly, the transformation known as pronuclei (Rajabi et al., 2017). Pronuclei is the last stage of sperm transformation with conspicuous of nuclear envelope, completion of nucleolus precursor development, advance change on chromatin distribution, and nuclear envelope modification (Lassalle and Testart, 1991). On the other hand, as a result of sperm stimulation leads to meiosis resumption of oocyte and female pronuclei formation (Elder and Dale, 2011). Cytoskeleton assists the migration of two pronuclei to the equatorial part of the oocyte and ended with syngami (Wan-Hafizah et al., 2015).

The sperm nuclear transformation during in vitro fertilization closely related to incubation time of sperm with oocytes and varies among species depend also on the laboratory. In cattle the incubation time for in vitro fertilization takes 16 hours (Xu and Greve, 1988), 14-18 hours in porcine (Laurincik et al., 1994) and there still no report in the sheep oocytes. It is possible for each species to have different needs in incubation time, caused by species specific. However, the prolongation of incubation time increases the incident of polyspermia (Sattar et al., 2011). The understanding of tranformation process of sheep sperm is necessary to increase the fertilization rate and decrease polyspermia that which cause the increasing of embryo development rate. Therefore, the objective of this result was to analyze the transformation process after fertilization and time is required for incubation of sperm and oocyte in the in vitro embryo production.

\section{MATERIALS AND METHODS}

\section{Oocytes Collection and In Vitro Maturation}

The ovaries $( \pm 318)$ were collected from local slaughterhouse and transfered to laboratory in $\mathrm{NaCl} \quad 0.9 \%$ solution which added with penicillin $(100 \mathrm{IU} / \mathrm{ml})$ and streptomycin $(0.1$ $\mathrm{mg} / \mathrm{ml}$ ) at $35-37^{\circ} \mathrm{C}$ (Karja et al., 2013). Oocytes were recovered from follicles by slicing the ovary in phosphate buffered saline which was added with $0.3 \%$ bovine serum albumin (BSA) (SigmaAldrich Inc. A-7030), $100 \mathrm{IU} / \mathrm{ml}$ penicillin (Sigma-Aldrich, St. Louis, MO, USA), and 0.1 $\mathrm{mg} / \mathrm{ml}$ streptomycin (Sigma-Aldrich). The criteria of oocytes which were used in this research based on homogenous cytoplasmic appearance and the compactness of three layers cummulus cells (Yasmin et al., 2015). Oocytes were then matured for $24 \mathrm{~h}$ according to methods that reported by Karja et al. (2013) with minor modification. The collected oocytes were washed three times in tissue culture medium (TCM) 199 (Gibco) added with $0.3 \%$ BSA (Sigma-Aldrich. Inc, A-7030), 10 $\mathrm{IU} / \mathrm{ml}$ follicle stimulation hormone (FSH) (Kyoritsu Seiyaku, Japan), $10 \mathrm{IU} / \mathrm{ml}$ human chorionic gonadotropin (hCG) (Intervet BoxmeerHolland), and $50 \mu \mathrm{g} / \mathrm{ml}$ gentamycin (Sigma, P4687). The solution was equilibrated previously in incubator for 2 hours. The oocytes was matured in $100 \mu 1$ maturation medium for each $10-15$ oocytes and covered with mineral oil (Sigma, M-8410). 
The maturation process was carried out in incubator at $38.5^{\circ} \mathrm{C}$ with $5 \% \mathrm{CO}_{2}$.

\section{In Vitro Fertilization and Evaluation of Transformation Sperm Nuclei}

The fertilization process was carried out according to Pamungkas et al. (2012) with minor modifications. The frozen semen was thawed in warm water at $35^{\circ} \mathrm{C}$ for 30 seconds. Semen then placed in fertilization medium (Suzuki et al., 2000) then setrifuged in $630 \mathrm{~g}$ for 5 minutes. The supernatant then removed and $200 \mu \mathrm{l}$ of remaining pellet diluted with fertilization medium until the final concentration reach $5 \times 10^{6}$ $\mathrm{sperm} / \mathrm{ml}$ (Kang et al., 2015). The matured oocytes washed 3 times with fertilization medium without sperm and then placed into $100 \mu 1$ drop fertilization media which covered with mineral oil (Sigma-Aldrich, USA) (Hasbi et al., 2017). Oocytes and sperm then incubated for 3, 6, 9, 12, 15 at $38.5^{\circ} \mathrm{C}$ with $5 \% \mathrm{CO}_{2}$.

At the end of each fertilization period, the oocytes were fixed in methanol and acetic acid solution (3:1) for 48 hours and then were stained with 2\% aceto-orcein (Yasmin et al., 2015). Sperm nuclear transformation was evaluated according to sperm nuclear status of sperm, such as condensation, decondensation, and formation of prepronuclei and pronuclei. Condensation of sperm characterized by sharpening of the sperm head (Dozortsev et al., 1994). Decondensation indicated by increasing size and swelling of the sperm's head (Tesarik and Kopecny, 1989). Prepronuclei is a reform stage of the nuclear envelope. Pronuclei is the last stage of sperm transformation with conspicuous of nuclear envelope (Lassalle and Testart, 1991; Rajabi et al., 2017). Evaluation was conducted using phase contrast microscope (Olympus XI, Japan).

\section{Data Analysis}

The sperm nuclear transformation were described qualitatively by pictures. Quantitative data obtained from the percentage of sperm transformation. The data is showed as percentage and standard error means (SEM). The percentage of sperm transformation were analyzed with ANOVA and the differences between treatments were analyzed using Duncan test.

\section{RESULTS AND DISCUSSION}

\section{The Journey of Ram Sperm Transformation}

The transformation process of sperm in oocyte cytoplasm after in vitro fertilization in this research was observed every 3 hours for 15 hours. The indicators of transformation stages are observed by the transformation of sperm head, existence of second polar body and nuclear envelope as shown in Figure 1.

The first stage of sperm transformation was sperm condensation which was observed after 3 hours fertilization period. In that stage, inner acrosomal membrane fused with oocyte cytoplasm, resulted in disappearance of sperm nuclear envelope and acrosomal membranes and elongation of sperm head (Figure 1a). The first step of sperm transformation which can be seen is condensation (Hafez and Hafez, 2013) or decondensation (Lassalle and Testart, 1991) of sperm head. Sperm condensation characterized by leakage of sperm membrane (Tesarik and Kopecny, 1989). The sperm's head that have been undergone condensation were seen elongated as a result of nuclear envelope loss and acrosomal membrane fusion with oocyte cytoplasm (Figure 1a).

The transformation process then continued to sperm nuclear decondensation. Sperm nuclear decondensation occurred after 3 hours after fertilization period which was characterized by swelling of the sperm head (Tesarik and Kopecny, 1989) (Figure 1b). In this research, sperm condensation and decondensation was seen at 3 hours after fertilization period. Sperm transformation process of condensation into dencondensation happened rapidly, hence the decondensation often seen at the first observation (Crozet, 1988; Lassalle and Testart, 1991; Tesarik and Kopecny, 1989). At the same time, the nuclear status of oocyte resumed second meiotic divison toward anaphase II and telophase II (Figure 1c). Sperm head transformation occurred the oocyte became activated due to the increase of intracellular $\mathrm{Ca}^{2+}$ (Ickowicz et al., 2012; Miao and Williams, 2012).

Prepronuclei was the next sperm transformation form. The formation of male and female prepronuclei almost occurred at the same time at 6 hours after fertilization period. Prepronuclei characterized by a set of chromatin and nuclear envelope when still incomplete (Figure 1d). Wu et al. (2017) argue that prepronuclei formation which characterized by flattened vesicle that was adjacent with nucleoplasm hence nuclear envelope was faintly visible.

The last stage of sperm transformation was 


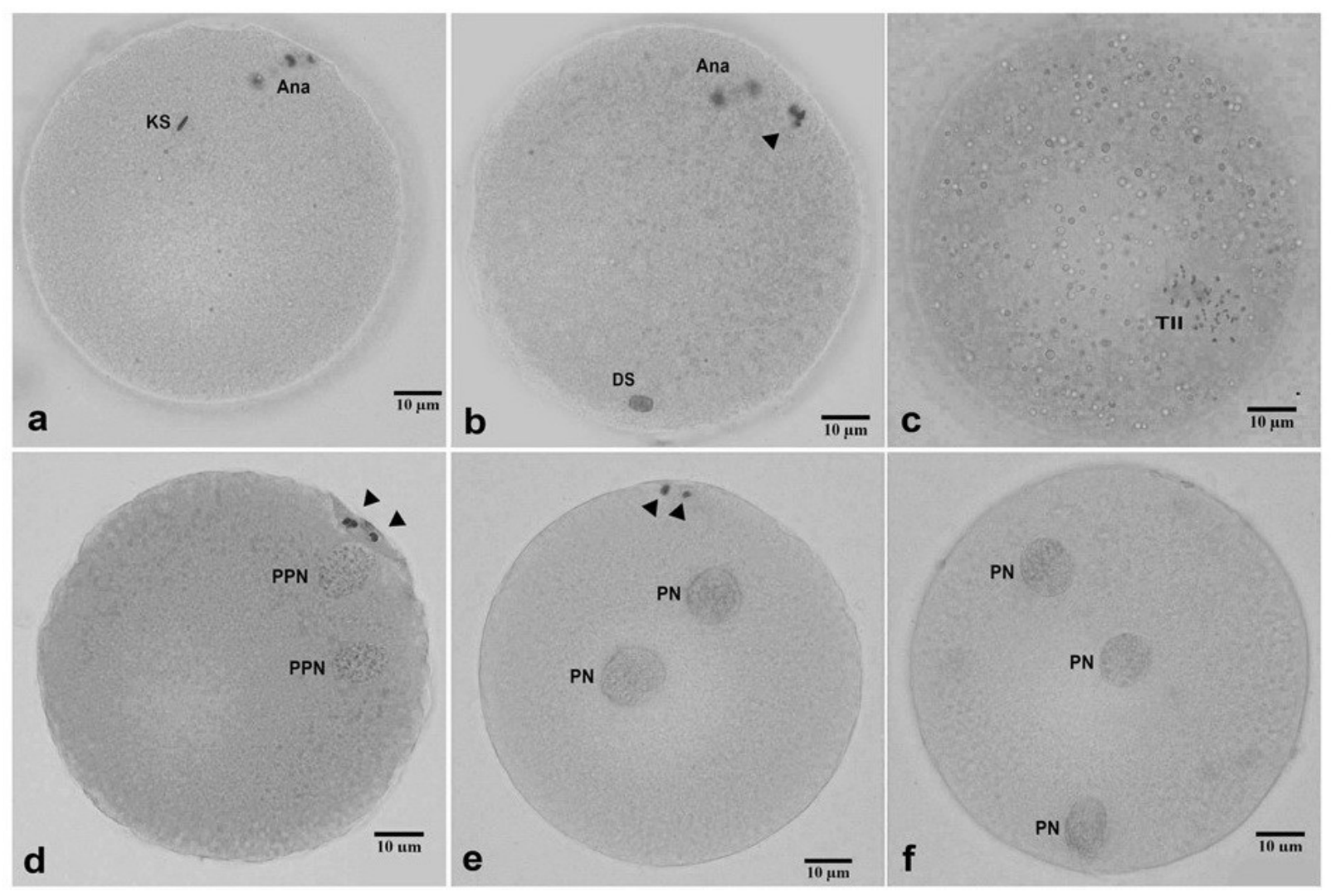

Figure 1. Sperm nuclear transformation in oocyte cytoplasm. (a) condesed sperm after 3 hours, (b) sperm decondesed and anaphase II of nuclear oocyte, PBI appear, (c) appearance of TII which spread oocyte nucleus, (d) 2 prepronuclei with PBII formed after 6 hours, (e) 2 pronucleus have formed after 6 hours \& PBII appear, (f) $>2 \mathrm{PN}$ indicated polyspermia. $\mathrm{KS}=$ condensed sperm; $\mathrm{DS}=$ decondesed sperm;

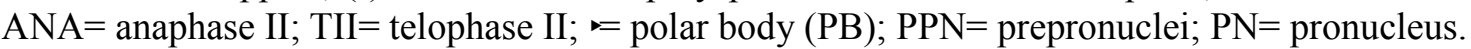

the formation of complete pronuclei. The formation of pronuclei was found at 6 hours after the interaction sperm-oocytes. A second polar body was extruded along with pronuclei formation (Figure 1e). Six hours after incubation, pronuclei had been formed which was characterized by increase in size, complete formation of nuclear envelope which became clearly visible (Figure 1e).

Transfromation of sperm until pronuclei formation in porcine takes 14-18 hours (Laurincik, 1994), while in cattle is 16 hours (Xu and Greve, 1988). Period of sperm transformation process varies among species, therefore the information regarding optimum time of fertilization is neccessary. The rapid transformation of sperm to be decondensed was influenced by sperm nucleus-decondensing factor (SNDF) (Hirao and Yangimachi, 1979). The existance of SNDF in cytoplasm begin with gerimal vesicle breakdown and continue to increase until oocyte maturation (Mahi and Yanagimachi, 1976). Reported by Nasr-Esfahani et al., (2010) and Alvarez et al., (2013) proved that fertilization of immature oocytes lead to sperm transformation failure. Penetration of sperm into mature oocyte cytoplasm leads to oocyte activation (Aarabi et al., 2014; White et al., 2010), hence at the same time oocyte resumes its second meiosis (Figure 1a and 1b). The process of second meiosis leads to an advanced status of oocyte which characterized by second anaphase-telophase formation. Sitiayu et al., (2005) confirmed that the formation of clear second telophase was an indication of chromatin distribution. Sperm activates phospholipase C which leads to inositol 1, 4, 5-triphosphate (IP3) activation and $\mathrm{Ca}^{2+}$ release (Amdani et al., 2013; Kashir et al., 2012; Zhang et al., 2011). The increase of $\mathrm{Ca}^{2+}$ leads to decrease in MPF so, the 
second meiosis is resumed and completed, then female pronuclei and second polar body is released (Elder and Dale, 2011; Sanders and Swann, 2016).

\section{Ram Sperm Transformation after Incubation}

Penetration of sperm with oocytes was penetrated 3 hours after sperm-oocytes incubation. Sperm have been transformed to pronucleus 6 hours and the percentage of pronucleus was increased as the fertilization period prolonged (Table 1).

The percentage of sperm transformation for each fertilization period was showed in Table 1. Three hours after fertilization period no sperm were turned into pronucleus, $28.7 \%$ became condensed while $50.9 \%$ were decondensed. Six hours after fertilization period, the formation of pronuclei was significantly increased to $30.3 \%$ $(\mathrm{P}<0.05)$, while condensation and decondensation of sperm were significantly decreased $(\mathrm{P}<0.05)$ to $7 \%$ and $23.5 \%$ respectively. Those result are consistent with Elder and Dale (2011) which reported that at 6 hours after fertilization period, small microtubules grow out from sperm centrosome and the activates oocyte produces second polar body. The condensation and decondensation were significantly decreased while the formation of pronuclei was sign in
$(\mathrm{P}<0.05)$ with prolonged incubation time. Six hours after fertilization period, some male and female pronuclei located on the oocyte edge, and both pronuclei have completely migrated to the center of oocyte at 9 hours after incubation. These microtubules play a role in directing the male pronucleus migration to the center of oocyte and contact with female pronucleus (Almonacid et al., 2018; Chaigne et al., 2016). Furthermore, actin and cytoskeletal inside cytoplasm also involves in pronucleus migration (Chaigne et al., 2016) and greater developmental competence to cleavage rate (Wan-Hafizah et al., 2015). It shows that microtubules play a role to assist migration process at 6 hours after incubation period, hence at 9 hours of fertilization pronuclei have located at the center of oocyte.

Prepronuclei formation began at 6 hours and increased until 9 hours of incubation. Prepronuclei $(14.3 \%)$ was significantly increased $(\mathrm{P}<0.05)$ followed by pronuclei formation $(47.1 \%)$ at 9 hours of incubation. In prepronuclei stage, nuclear envelope was not clearly seen. Nuclear envelope was formed by fusion of vesicles which needs GTP (Lete et al., 2017; Ungricht and Kutay, 2017). The binding process of vesicles within chromatin was mediated by lamin B receptor (LBR). In nucleus, lamin B associated with LBR and leads to pronucleus

Table 1. Ram Sperm Transformation after Interaction of Sperm-oocytes for 15 Hours

\begin{tabular}{|c|c|c|c|c|c|c|c|}
\hline \multirow{2}{*}{$\begin{array}{l}\text { IVF } \\
\text { period } \\
\text { (hours) }\end{array}$} & \multirow{2}{*}{$\begin{array}{l}\text { Number } \\
\text { of } \\
\text { Oocytes } \\
\text { (n) }\end{array}$} & \multicolumn{5}{|c|}{ Sperm Transformation $\% \pm$ SE (n) } & \multirow{2}{*}{$\begin{array}{c}\text { Fertilization } \\
\text { Rate } \% \pm \mathrm{SE} \\
\text { (n) }\end{array}$} \\
\hline & & $\mathrm{KS}$ & DS & $2 \mathrm{PPN}$ & $2 \mathrm{PN}$ & $>2 \mathrm{PN}$ & \\
\hline 3 & 129 & $\begin{array}{c}28.7 \pm 7.8^{\mathrm{a}} \\
(38)\end{array}$ & $\begin{array}{c}50.9 \pm 5.8^{\mathrm{a}} \\
(65)\end{array}$ & $\begin{array}{c}0.0 \pm 0.0^{\mathrm{a}} \\
(0)\end{array}$ & $\begin{array}{c}0.0 \pm 0.0^{\mathrm{a}} \\
(0)\end{array}$ & $\begin{array}{c}0.0 \pm 0.0^{\mathrm{a}} \\
(0)\end{array}$ & $\begin{array}{c}79.6 \pm 4.7 \\
(103)\end{array}$ \\
\hline 6 & 123 & $\begin{array}{c}7.0 \pm 41^{b} \\
(8)\end{array}$ & $\begin{array}{c}23.5 \pm 8.1^{b} \\
(28)\end{array}$ & $\begin{array}{c}1.9 \pm 1.1^{\mathrm{a}} \\
(2)\end{array}$ & $\begin{array}{c}30.3 \pm 5.2^{\mathrm{b}} \\
(37)\end{array}$ & $\begin{array}{c}11.7 \pm 5.5^{\mathrm{ab}} \\
\quad(13)\end{array}$ & $\begin{array}{c}74.3 \pm 12.3 \\
(88)\end{array}$ \\
\hline 9 & 129 & $\begin{array}{c}0.8 \pm 0.8^{b} \\
\quad(1)\end{array}$ & $\begin{array}{c}7.4 \pm 3.0^{\mathrm{c}} \\
(9)\end{array}$ & $\begin{array}{c}14.3 \pm 4.9^{b} \\
(19)\end{array}$ & $\begin{array}{c}47.1 \pm 6.4^{\mathrm{c}} \\
\quad(60)\end{array}$ & $\begin{array}{c}8.2 \pm 3.0^{\mathrm{ab}} \\
(11)\end{array}$ & $\begin{array}{c}77.8 \pm 3.1 \\
\quad(100)\end{array}$ \\
\hline 12 & 129 & $\begin{array}{c}0.0 \pm 0.0^{b} \\
(0)\end{array}$ & $\begin{array}{c}0.0 \pm 0.0^{\mathrm{c}} \\
\quad(0)\end{array}$ & $\begin{array}{c}0.0 \pm 0.0^{\mathrm{a}} \\
\quad(0)\end{array}$ & $\begin{array}{c}49.7 \pm 4.5^{\mathrm{c}} \\
(48)\end{array}$ & $\begin{array}{c}19.4 \pm 5.6^{\mathrm{b}} \\
(21)\end{array}$ & $\begin{array}{c}68.6 \pm 2.6 \\
(69)\end{array}$ \\
\hline 15 & 125 & $\begin{array}{c}0.0 \pm 0.0^{b} \\
(0)\end{array}$ & $\begin{array}{c}0.0 \pm 0.0^{\mathrm{c}} \\
(0)\end{array}$ & $\begin{array}{c}0.0 \pm 0.0^{\mathrm{a}} \\
(0)\end{array}$ & $\begin{array}{c}52.6 \pm 6.0^{\mathrm{c}} \\
(65)\end{array}$ & $\begin{array}{c}22.5 \pm 7.1^{b} \\
(35)\end{array}$ & $\begin{array}{c}75.0 \pm 5.7 \\
(100)\end{array}$ \\
\hline
\end{tabular}

$\mathrm{KS}=$ condensed sperm; $\mathrm{DS}=$ decondesed sperm; $2 \mathrm{PPN}=$ two prepronuclei; $2 \mathrm{PN}=$ two pronuclei; $>2 \mathrm{PN}=$ more than two pronuclei; ${ }^{\mathrm{a}-\mathrm{c}}=$ in the same column show significant differences $(\mathrm{P}<0.05)$. 
swelling (Dittmer and Misteli, 2011).

Furthermore, the formation of condensed and decondensed sperm decreased at 9 hours of fertilization and dissappeared at 12 hours of incubation period due to the transformation of sperm into pronucleus (49.7\%). At the end of 1215 hours of incubation, polyspermia was significantly increased $(\mathrm{P}<0.05)$. Polyspermia significantly increased with the prolongation of fertilization time $(\mathrm{P}<0.05)$. Sattar et al., (2011) and Long et al., (1994) confirmed that too long fertilization time leads to the increase in polyspermia. The length of time IVF is associated with the occurrence of aneuploidy (Gould and Griffin, 2018). Liu et al., (2016) reported that the reduction fertilization time will increase the efficiency of fertilization. Reduction of fertilization time also recommended by Enkhmaa et al., (2009) which confirmed that the increase too long fertilization time leads to reactive oxygen species (ROS). ROS have negative effects to increase DNA fragmentation on sperm (Cicare et al., 2014), fertilization rate in IVF and the embryo development (Goncalves et al., 2010; Lopes et al., 2010; Bain et al., 2010). Increased ROS can be caused spermatozoa produce ROS (Olmo et al., 2014; Abreu et al., 2017) therefore, the prolonged exposure sperm-oocytes can add to the accumulation of increased ROS. The other effects, immature (Yamaguchi and Kuroda, 2018) and over matured oocytes reduce the effectiveness of cortical granules, so reducing the incubation time of fertilization reduces the level of polyspermia (Long et al., 1994).

Several reports suggested that the optimum time of fertilization was 4 hours in mice (Enkhmaa et al., 2009), 8 hours in bovine (Long et al., 1994), and 6 hours in porcine (Alminana et al., 2005). The optimum fertilization time leads to increase monospermia, fertilization rate efficiency, and succesfull rate of embryo development. In this research also shows the same result that the fertilization more than 12 hours is not recommended due to increase in polyspermia.

\section{CONCLUSION}

Penetration of sperm into oocytes has been occurred at 3 hour of fertilization period. The formation of pronuclei was found at six hours after fertilization period and the incidence of polyspermia increased as the fertilization period prolonged.

\section{REFERENCES}

Aarabi, M., H. Balakier, S. Bashar, S.I. Moskovtsev, P. Sutovsky, C.L. Librach, and R. Oko. 2014. Sperm-derived WW domain-binding protein, PAWP, elicits calcium oscillations and oocyte activation in humans and mice. FASEB. J. 28(10): 4434-4440.

Abreu, D.G., S.G. Martinez, V.F. Espin, R. Romar, and J. Gadea. 2017. Incubation of boar spermatozoa in viscous media by addition of methylcellulose improves sperm quality and penetration rates during in vitro fertilization. Theriogenology. 92: 14-23.

Alminana, C., M.A. Gil, C. Cuello, J. Roca, J.M. Vazquez, H. Rodriguez-Martinez and E.A. Martinez. 2005. Adjustments in IVF system for individual boars: value of additives and time of sperm-oocyte co-incubation. Theriogenology. 64: 1783-1796.

Almonacid, M., M.E. Terret, and M.H. Verlhac. 2018. Control of nucleus positioning in mouse oocytes. Semin. Cell Dev. Biol. 82: $34-40$.

Álvarez, C., C. García-Garrido, R. Taronger and G.G. de Merlo. 2013. In vitro maturation, fertilization, embryo development \& clinical outcome of human metaphase-I oocytes retrieved from stimulated intracytoplasmic sperm injection cycles. Indian J. Med. Res. 137(2):331-338.

Amdani, S.N., C. Jones and K. Coward. 2013. Phospholipase C zeta (PLC)): Oocyte activation and clinical links to male factor infertility. Adv. Biol. Regul. 53(3): 292-308.

Bain, N.T., P. Madan, and D.H. Betts. 2010. The early embryo response to intracellular reactive oxygen species is developmentally regulated. Reprod. Fert. Develop. 23(4): 561-575.

Bianchi, E. and G. J. Wright. 2016. Sperm meets eggs: the genetics of mammalian fertilization. Annu. Rev. Genet. 50:93-111.

Chaigne, A., C. Campillo, R. Voituriez, N.S. Gov, C. Sykes, M.H. Verlhac and M.E. Terret. 2016. F-actin mechanics control spindle centring in the mouse zygote. Nat. Commun. 7:10253.

Cicare, J., A. Caille, C. Zumoffen, S. Ghersevich, L. Bahamondes and M.J. Munuce. 2014. In vitro incubation of human spermatozoa promotes reactive oxygen species generation and DNA fragmentation. 
Andrologia. 47(8):861-866.

Crozet, N. 1988. Ultrastructural aspects of in vitro fertilization in sheep. J. Ultra. Mol. Struct. Res. 98: 1-10.

Dittmer, T.A. and T. Misteli. 2011. The lamin protein family. Genom. Biol. 12(222):1-14.

Dozortsev, D., P. Sutter and M. Dhont. 1994. Behaviour of spermatozoa in human oocytes displaying no or one pronucleus after intracytoplasmic sperm injection. Hum. Reprod. 9(11):2139-2144.

Elder, K. and B. Dale. 2011. In Vitro Fertilization Third Edition. Cambridge University Press. United Kingdom.

Enkhmaa, D., T. Kasai and K. Hoshi. 2009. Longtime exposure of mouse embryos to the sperm produced high level of reactive oxygen species in culture medium and relates to poor embryo development. Reprod. Dom. Anim. 44:634-637.

Gilbert, S.F. 2010. Developmental Biology Fifth Edition. Sinauer Associates Inc. Massachusetts.

Goncalves, F.S., L.S.S. Barretto, R.P. Arruda, S.H.V. Perri, and G.Z. Mingoti. 2010. Effect of antioxidants during bovine in vitro fertilization procedures on spermatozoa and embryo development. Reprod. Domest. Anim. 45(1):129-135.

Gould, R.L. and D.K. Griffin. 2018. Aneuploidy status is associated with the length of time that the pronuclei are visible. Reprod. Biomed. Online 36(1):26-27.

Hafez, E.S.E. and B. Hafez. 2013. Reproduction in Farm Animals $7^{\text {th }}$ edition. Lippincott Williams \& Wilkins. Philadelphia.

Hasbi, H., S. Gustina, N.W.K. Karja, I. Supriatna and M.A. Setiadi. 2017. Insulin-like growth factor-I concentration in the follicular fluid of bali cattle and its role in the oocyte nuclear maturation and fertilization rate. Med. Pet. 40(1):7-13.

Hino, T., Y. Muro, M.T. Nakano, M. Okabe, H. Tateno and R. Yanagimachi. 2016. The behavior and acrosomal status of mouse spermatozoa in vitro and within the oviduct during fertilization after natural mating. Biol. Reprod. 95(3):1-11.

Hirao, Y. and R. Yanagimachi. 1979. Development of pronuclei in polyspermic eggs of the golden hamster: Is there any limit to the number of sperm heads that are capable of developing into male pronuclei? Zool. Mag. 88:24-33.
Hirohashi, N. and R. Yanagimachi. 2018. Sperm acrosome reaction: Its site and role in fertilization. Biol. Reprod. 99 (1): 127-133.

Ickowicz, D., M. Finkelstein and H. Breitbart. 2012. Mechanism of sperm capacitation and the acrosome reaction: role of protein kinases. Asian J. Androl. 14(6):816-821.

Jin, M., E. Fujiwata, Y. Kakiuchi, M. Okabe, Y. Satouh, S.A. Baba, K. Chiba and N. Hirohashi. 2011. Most fertilizing mouse spermatozoa begin after acrosome reaction before contact with the zona pellucida during in vitro fertilization. PNAS 108(12): 4892-4896.

Kang S.S., K. Koyama, W. Huang, Y. Yanagawa, Y. Takahashi and M. Nagano. 2015. Addition of D-penicillamine, hypotaurine, and epinephrine (PHE) mixture to IVF medium maintains motility and longevity of bovine sperm and enhances stable production of blastocysts in vitro. J. Reprod. Develop. 61(2):99-105.

Karja, N.W.K., M. Fahrudin and M. A. Setiadi. 2013. In vitro fertility of post-thawed epididymal ram spermatozoa after storage at $5^{\circ} \mathrm{C}$ before cryopreservation. Med. Pet.: 26-31.

Kashir, J., C. Jones, and K. Coward. 2012. Calcium oscillations, oocyte activation, and phospholipase $\mathrm{C}$ zeta. In: Calcium Signaling. (Md.S. Islam, ed). Springer. Switzerland. P.1095-1121.

La Spina, F. A., C. Stival, D. Krapf and M. G. Buffone. 2017. Molecular and cellular aspects of mammalian sperm acrosomal exocytosis. In: Animal Models and Human Reproduction. (H. Schatten, and G. M. Constantinescu, eds). John Wiley \& Sons Inc. New Jersey. P.409-416.

Lassalle, B. and J. Testart. 1991. Sequential transformation of human sperm nucleus in human eggs. J. Reprod. Fert. 91: 393-402.

Laurincik, J., D. Rath and H. Niemann. 1994. Differences in pronucleus formation and first cleavage following in vitro fertilization between pig oocytes matured in vivo and in vitro. J. Reprod. Fert. 102:277-284.

Lete, M.G., R.D. Byrne, A. Alonso, D. Poccia and B. Larijani. 2017. Vesicular PtdIns $(3,4,5) \mathrm{P}_{3}$ and Rab7 are key effectors of sea urchin zygote nuclear membrane fusion. J. Cell. Sci. 130:444-452.

Liu, J., X. Zhang, Y. Yang, J. Zhao, D. Hao, J. 
Zhang, Y. Liu, W. Wu, and X. Wang. 2016. Long-time vs. short-time insemination of sibling eggs. Exp. Ther. Med. 12(6):37563760.

Long, C.R., P. Damiani, C. Pinto-Correia, R.A. MacLean, R.T. Duby and J.M. Robl. 1994. Morphology and subsequent development in culture of bovine oocytes matured in vitro under various conditions of fertilization. J. Reprod. Fert. 102: 361-369.

Lopes, A.S., M. Lane and J.G. Thompson. 2010. Oxygen consumption and ROS production are increased at the time of fertilization and cell cleavage in bovine zygotes. Hum. Reprod. 25(11): 2762-2773.

Mahi, C. A. and R. Yanagimachi. 1976. Maturation and sperm penetration of canine ovarian oocytes in vitro. J. Exp. Zool. 196: 189-196.

Miao, Y.L. and C.J. Williams. 2012. Calcium signaling in mammalian egg activation and embryo development: The influence of subcellular localization. Mol. Reprod. Dev. 79(11): 742-756.

Miyado, K., K. Yamatoya, W. Kang and N. Kawano. 2018. Regulation of sperm-egg fusion at the plasma membrane. In: Diversity and Commonality in Animals. (K. Kobayashi, T. Kitano, Y. Iwao, and M. Kondo, eds). Springer. Tokyo. P.549-568.

Nasr-Esfahani, M.H., M.R. Deemeh and M. Tavalaee. 2010. Artificial oocyte activation and intracytoplasmic sperm injection. Fertil Steril. 94(2): 520-526.

Olmo, E.D., A. Bisbal, O.G. Alvarez, A.M. Morales, M. Ramon, P.J. Rabadan, L.A. Lopez, A.J. Soler, J.J. Garde and M.R.F. Santos. 2014. Free-radical production after post-thaw incubation of ram spermatozoa is related to decreased in vivo fertility. Reprod. Fert. Develop. 27(8) 1187-1196.

Pamungkas, F.A., M.A. Setiadi and N.W.K. Karja. 2012. Characteristics and in vitro fertilization ability of ram spermatozoa: comparison of epididymal and ejaculated spermatozoa. Med. Pet. 35(1):38-44.

Rajabi, H., H.M. Kouchesfehani, T.E. Arshaghi, M. Salehi. 2017. Sperm DNA fragmentation affects epigenetic feature in human male pronucleus. Andrologia 50(1): e12800.

Sanders, J.R. and K. Swann. 2016. Molecular triggers of egg activation at fertilization in mammals. Reproduction 152(2):R41-R50.

Sattar, A., M. Rubessa, S. Di Francesco, V.
Longobardi, R. Di Palo, L. Zicarelli, G. Campanile, and B. Gasparrini. 2011. The influence of gamete co-incubation length on the in vitro fertility and sex ratio of bovine bulls with different penetration speed. Reprod. Domest. Anim. 46(6):1090-1097.

Sharma, P. J. and K. A. Rao. 2018. The human sperm and egg: key players of fertilization. In: The Infertility Manual Fourth Edition. (K. A. Rao, and Divyashree, eds). Jaypee Brothers Medical Publishers. New Delhi. P.9-15.

Suzuki, K., B. Eriksson, H. Shimizu, T. Nagai and H. Rodriguez-Martinez. 2000. Effect of hyaluronan on monospermic penetration of porcine oocytes fertilized in vitro. Int. J. Androl. 23:13-21.

Tesarik, J. and V. Kopecny. 1989. Development of human male pronucleus: Ultrastructure and timing. Gamete. Res. 24: 135-149.

Ungricht, R., and U. Kutay. 2017. Mechanisms and functions of nuclear envelope remodelling. Nat. Rev. Mol. Cell Biol. (18): 229-245.

Wan-Hafizah, W.J, M.N.K. Nor-Ashikin, M.H. Rajikin, A.S. Nuraliza, H. Zainuddin, A.R. Nor-Shahida, O. Salina, D. Razif, J. Norhazlin, M. Mohd-Fazirul, K. A. NurSakina, M. Kapitonova. 2015. Organization of cytoskeleton and chromatin is related to the timing of the first zygotic cleavage and early developmental competence. Biomed. Res. 26(2):286-292.

White, K.L., B.J. Pate and B.R. Sessions. 2010. Oolemma receptors and oocyte activation. Syst. Biol. Reprod. Med. 56(5): 365-375.

Wu, K., T. Chen, S. Huang, C. Zhong, J. Yan, X. Zhang, J. Li, Y. Gao, H. Zhao and Z.J. Chen. 2017. Mitochondrial replacement by pre-pronuclear transfer in human embryos. Cell Res. 27:834-837.

Xu, K.P. and T. Greve. 1988. A detailed analysis of early event during in-vitro fertilization of bovine follicular oocytes. J. Reprod. Fert 82(1):127-134.

Yamaguchi, T., K. Kuroda, A. Tanaka and S. Watanabe. 2018. Fertilization failure. In: Treatment Strategy for Unexplained Infertility and Recurrent Miscarriage. (K. Kuroda, J.J. Brosens, S. Quenby, and S. Takeda, eds). Springer Nature. Switzerland. P.7-17.

Yasmin, C., T. Otoi, M.A. Setiadi and N.W.K. Karja. 2015. Maturation and fertilisation of 
sheep oocytes cultured in serum-free medium containing silk protein sericin. Acta. Vet. Hung. 63:110-117.

Zhang, S., N. Fritz, C. Ibarra, P. Uhlén. 2011.
Inositol 1,4,5-Trisphosphate receptor subtype-specific regulation of calcium oscillations. Neurochem. Res. 36(7):11751185. 